\title{
Factors controlling colonic motility: Colonic pressures and transit after meals in patients with total gastrectomy, pernicious anaemia or duodenal ulcer
}

\author{
D. J. HOLDSTOCK AND J. J. MISIEWICZ \\ From the Medical Research Council Gastroenterology Unit, Central Middlesex Hospital, London
}

SUMMARY The motor responses of the proximal colon, sigmoid, and rectum to the ingestion of a standard meal have been compared in patients with total gastrectomy, pernicious anaemia, or duodenal ulcer. Colonic pressure activity increased during and after food in all the patients, but this was only once associated with propulsive activity. The results suggest that the postprandial pressure activity in the sigmoid colon is greater after total gastrectomy than in the other two groups. It is concluded that entry of food into the upper small intestine is the most important factor in initiating the colonic pressure response to food, since this response does not require the presence of the stomach, acid, antral gastrin, or of vagal innervation.

Abnormalities of colonic motility are important in the pathogenesis of a number of disorders, such as diverticular disease (Morson, 1963; Arfwidsson, 1964; Painter, Truelove, Ardran, and Tuckey, 1965), the irritable colon syndrome (Chaudhary and Truelove, 1962; Connell, Jones, and Rowlands, 1965), idiopathic megacolon, intractable constipation or diarrhoea, and the like; they are also important in the production of abdominal pain (Holdstock, Misiewicz, and Waller, 1969). Pressure activity in the human colon increases after meals, and eating is among the main physiological stimuli that affect colonic motility, but the factors which control this effect are largely unknown. It therefore was of interest to investigate the pathway through which the colonic response to meals is mediated. We have measured intraluminal pressures and transit in the colon of patients with pernicious anaemia, duodenal ulcer, or with total gastrectomy, and have compared their responses to a standard meal. The results suggest that entry of food into $\sigma$ the small intestine is of major importance in $N$ initiating the postprandial increase of colonic pressure activity.

\section{Patients and Methods}

The number of patients studied in the three diagnostic groups and their clinical features are listed in Table I.

In the seven patients with total gastrectomy, the operation had been performed from six months to 13 years previously; they all enjoyed good general health and a good appetite at the $\frac{\bar{a}}{7}$ time of the study. Six patients had a Roux-en-Y anastomosis and the seventh a jejunal reservoir. The pernicious anaemia group (nine patients) 


\begin{tabular}{|c|c|c|c|c|c|c|c|c|}
\hline \multirow{2}{*}{$\begin{array}{l}\text { Diagnostic } \\
\text { Group }\end{array}$} & \multirow{2}{*}{$\begin{array}{l}\text { No. of } \\
\text { Patients }\end{array}$} & \multirow{2}{*}{ Males } & \multirow[b]{2}{*}{ Females } & \multicolumn{2}{|l|}{ Age } & \multicolumn{3}{|c|}{$\begin{array}{l}\text { Records Available } \\
\text { for Analysis }\end{array}$} \\
\hline & & & & $\begin{array}{l}\text { Mean } \\
( \pm S E M)\end{array}$ & Range & & nal Sigmoid & Rectum \\
\hline \multirow{3}{*}{$\begin{array}{l}\text { Total } \\
\text { gastrectomy } \\
\text { Pernicious } \\
\text { anaemia } \\
\text { Duodenal } \\
\text { ulcer }\end{array}$} & 7 & 5 & 2 & $58( \pm 6 \cdot 4)$ & $22-84$ & 4 & 7 & 7 \\
\hline & 9 & 1 & 8 & $65( \pm 4 \cdot 5)$ & $50-83$ & 8 & 9 & 9 \\
\hline & 12 & 10 & 2 & $49( \pm 3 \cdot 8)$ & $25-66$ & 8 & 12 & 12 \\
\hline
\end{tabular}

Table I Clinical details of patients and records available for analysis

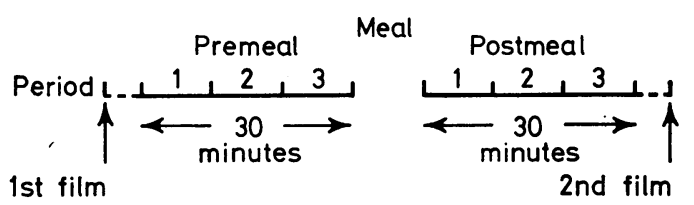

Fig. 1 Design of study.

consisted of either out-patients on maintenance $B_{12}$ treatment, or of recently diagnosed and treated inpatients who had a rising haemoglobin level of $>9.0 \mathrm{~g} \%$. The diagnosis had been established in all by low serum $B_{12}$ levels and achlorhydria to maximal stimulation with histalog; the majority had gastric autoantibodies, but none had evidence of neuropathy.

The 12 patients with duodenal ulcer were all inpatients admitted for surgery or convalescent from an episode of haematemesis and melaena; none had clinical or radiological evidence of pyloric stenosis or a high resting gastric juice volume. Maximal histalog tests were performed on them by standard procedure with a dose of 1.5 $\mathrm{mg} / \mathrm{kg}$ (Baron, 1963; Wormsley and Grossman, 1965).

\section{Measurement and Analysis of Intraluminal Pres- sures and of Transit Times}

Intraluminal pressures (IP) were measured simultaneously at three sites, one in the proximal and two in the distal colon. The proximal colon was defined for the purpose of this study as consisting of the caecum, ascending and transverse portions; measurements in the distal bowel were made in the sigmoid and the rectum.

Pressures in the proximal colon were telemetered with radiocapsules (Rowlands and Wolff, 1960) which were localized by fluoroscopy and the characteristics of the pressure record (Misiewicz, Waller, Fox, Goldsmith, and Hunt, 1968a). Pressures in the sigmoid and rectum were measured with $7 \times 10 \mathrm{~mm}$ air-filled balloons (Atkinson, Edwards, Honour, and Rowlands, 1957) connected by fine polyethylene tubing to transducers recording on a multi-channel penwriter (Sanborn). At sigmoidoscopy, the proximal balloon was placed at 20 to $25 \mathrm{~cm}$ and the distal at 10 to $15 \mathrm{~cm}$ from the anal margin. The pressure records were processed in an analogue to digital converter and analysed by computer (Misiewicz, Waller, Healy, and Piper, 1968b). Separate analyses were made for each 10-minute observation period and for the time interval during which the meal was eaten. Variables of motility derived from computer analysis included the motility index (MI) and percentage duration of activity, as defined previously (Misiewicz et al, 1968b). The motility index results were expressed as logarithms (to the base 10), because the distribution of these data was lognormal. Tests for significant differences between the 10-minute observation periods, or the meal period, were carried out with two-way analysis of variance.

Comparisons were always made at the same recording site, both between the various observation periods within each diagnostic category, and of the same observation period between the three groups of patients. Comparisons of the responses in the proximal with the distal colon were not considered meaningful, because of the different methods used to measure pressures at these sites (Misiewicz, 1968c; Misiewicz, Waller, and Holdstock, 1969b).

Colonic transit was measured with radiopaque pellets (Halls, 1965; Hinton, 1967; Hinton, Lennard-Jones, and Young, 1969) administered simultaneously with the radiotelemetering capsule. To detect propulsive activity, plain radiographs of the abdomen were taken at the start and finish of the study, the dose of radiation being minimized by the use of fast films exposed through intensifying screens (Kodak High Speed) and at low mA (Holdstock, Misiewicz, Smith, and Rowlands 1970). The skin dose did not exceed $60 \mathrm{mR} / \mathrm{film}$. The results were expressed as change, or otherwise, of the position of the pellets and of the radiotelemetering capsule in relation to bony landmarks. Under the conditions of the study all the pellets were in the colon by the time the first radiograph was taken. In addition, mouth-toanus transit times were measured by collecting the stools in cartons and counting the number of pellets in each stool specimen by fluoroscopy; the results were expressed as described by Hinton (1967).

\section{Design of Study}

The patients were given the radiotelemetering capsule and pellets on the evening before the test and fasted overnight. Half an hour after withdrawing the sigmoidoscope, basal activity was recorded for three consecutive 10-minute observation periods.An appetizing standard meal, comprising egg, toast and butter, tinned fruit, and tea, was then served. Recording of pressures continued during the meal, and for a further three 10-minute 


\begin{tabular}{|c|c|c|c|c|c|c|c|c|c|}
\hline \multirow[t]{3}{*}{ Site } & \multirow[t]{3}{*}{ Group } & \multicolumn{7}{|c|}{ Observation Period } & \multirow[t]{3}{*}{ $\pm S E M$} \\
\hline & & \multicolumn{3}{|c|}{ Pre-meal } & \multirow[t]{2}{*}{ Meal } & \multicolumn{3}{|c|}{ Post-meal } & \\
\hline & & 1 & 2 & 3 & & 1 & 2 & 3 & \\
\hline \multirow[t]{3}{*}{$\begin{array}{l}\text { Proximal } \\
\text { colon }\end{array}$} & \multirow{3}{*}{$\begin{array}{l}\text { Total } \\
\text { gastrectomy } \\
\text { Pernicious } \\
\text { anaemia } \\
\text { Duodenal } \\
\text { ulcer }\end{array}$} & 1.62 & $1 \cdot 31$ & $1 \cdot 35$ & 1.68 & $1 \cdot 38$ & $1 \cdot 79$ & $1 \cdot 75$ & $\pm 0 \cdot 18$ \\
\hline & & 0.93 & 0.95 & 0.83 & $1 \cdot 44$ & 1.54 & $1 \cdot 38$ & $1 \cdot 45$ & $\pm 0 \cdot 15$ \\
\hline & & 0.74 & 0.68 & 0.79 & 1.59 & $1 \cdot 47$ & $1 \cdot 18$ & 1.07 & \pm 0.19 \\
\hline \multirow[t]{3}{*}{ Sigmoid } & \multirow{3}{*}{$\begin{array}{l}\text { Total } \\
\text { gastrectomy } \\
\text { Pernicious } \\
\text { anaemia } \\
\text { Duodenal } \\
\text { ulcer }\end{array}$} & 1.08 & $1 \cdot 36$ & $1 \cdot 28$ & $1 \cdot 83$ & 2.06 & $2 \cdot 12$ & 2.00 & \pm 0.14 \\
\hline & & $1 \cdot 39$ & $1 \cdot 37$ & $1 \cdot 46$ & $1 \cdot 65$ & $1 \cdot 72$ & 1.80 & 1.60 & \pm 0.14 \\
\hline & & $1 \cdot 30$ & $1 \cdot 30$ & $1 \cdot 26$ & $1 \cdot 86$ & 1.77 & 1.49 & 1.69 & \pm 0.12 \\
\hline \multirow[t]{3}{*}{ Rectum } & \multirow{3}{*}{$\begin{array}{l}\text { Total } \\
\text { gastrectomy } \\
\text { Pernicious } \\
\text { anaemia } \\
\text { Duodenal } \\
\text { ulcer }\end{array}$} & 0.82 & 0.95 & 0.92 & 1.42 & $1 \cdot 37$ & $1 \cdot 35$ & 1.03 & \pm 0.13 \\
\hline & & 0.83 & 0.88 & 0.88 & $1 \cdot 34$ & $1 \cdot 32$ & 1.29 & $1 \cdot 23$ & \pm 0.14 \\
\hline & & 1.03 & 0.95 & 0.77 & 1.40 & $1 \cdot 31$ & 1.09 & $1 \cdot 19$ & \pm 0.13 \\
\hline
\end{tabular}

Table II Variations in log motility index (means $\pm S E M$ )

\begin{tabular}{|c|c|c|c|c|c|c|c|c|c|}
\hline \multirow[t]{3}{*}{ Site } & \multirow[t]{3}{*}{ Group } & \multicolumn{7}{|c|}{ Observation Period } & \multirow[t]{3}{*}{ $\pm S E M$} \\
\hline & & \multicolumn{3}{|c|}{ Pre-meal } & \multirow[t]{2}{*}{ Meal } & \multicolumn{3}{|c|}{ Post-meal } & \\
\hline & & 1 & 2 & 3 & & 1 & 2 & 3 & \\
\hline \multirow[t]{3}{*}{$\begin{array}{l}\text { Proximal } \\
\text { colon }\end{array}$} & \multirow{3}{*}{$\begin{array}{l}\text { Total } \\
\text { gastrectomy } \\
\text { Pernicious } \\
\text { anaemia } \\
\text { Duodenal } \\
\text { ulcer }\end{array}$} & $15 \cdot 5$ & $17 \cdot 8$ & $11 \cdot 1$ & $26 \cdot 1$ & $22 \cdot 8$ & $39 \cdot 5$ & $31 \cdot 6$ & \pm 4.5 \\
\hline & & $18 \cdot 2$ & $13 \cdot 5$ & $16 \cdot 0$ & $31 \cdot 1$ & $34 \cdot 4$ & $30 \cdot 8$ & 23.9 & $\pm 4 \cdot 4$ \\
\hline & & $9 \cdot 5$ & $8 \cdot 1$ & $14 \cdot 4$ & $39 \cdot 5$ & $29 \cdot 8$ & 20.5 & $18 \cdot 4$ & $\pm 5 \cdot 0$ \\
\hline \multirow[t]{3}{*}{ Sigmoid } & \multirow{3}{*}{$\begin{array}{l}\text { Total } \\
\text { gastrectomy } \\
\text { Pernicious } \\
\text { anaemia } \\
\text { Duodenal } \\
\text { ulcer }\end{array}$} & $14 \cdot 0$ & $16 \cdot 3$ & $13 \cdot 2$ & $38 \cdot 5$ & $53 \cdot 0$ & $62 \cdot 8$ & 52.9 & $\pm 4 \cdot 8$ \\
\hline & & $26 \cdot 2$ & $21 \cdot 5$ & $27 \cdot 3$ & $34 \cdot 8$ & $39 \cdot 1$ & $39 \cdot 7$ & 37.9 & $\pm 4 \cdot 4$ \\
\hline & & $24 \cdot 4$ & $22 \cdot 4$ & $24 \cdot 5$ & $53 \cdot 2$ & $47 \cdot 2$ & $42 \cdot 2$ & $41 \cdot 4$ & \pm 3.9 \\
\hline \multirow[t]{3}{*}{ Rectum } & \multirow{3}{*}{$\begin{array}{l}\text { Total } \\
\text { gastrectomy } \\
\text { Pernicious } \\
\text { anaemia } \\
\text { Duodenal } \\
\text { ulcer }\end{array}$} & $14 \cdot 8$ & $17 \cdot 0$ & $17 \cdot 6$ & 30.8 & $31 \cdot 2$ & $35 \cdot 4$ & $25 \cdot 2$ & $\pm 3 \cdot 8$ \\
\hline & & $19 \cdot 5$ & $15 \cdot 5$ & $17 \cdot 7$ & $26 \cdot 3$ & $23 \cdot 2$ & $22 \cdot 6$ & $22 \cdot 5$ & $\pm 3 \cdot 1$ \\
\hline & & $20 \cdot 7$ & $19 \cdot 5$ & $14 \cdot 7$ & $36 \cdot 5$ & 30.8 & $27 \cdot 7$ & $28 \cdot 0$ & $\pm 4 \cdot 4$ \\
\hline
\end{tabular}

Table III Variations in percentage activity (means $\pm S E M$ )

observation periods timed from the end of the meal (Figure 1). During the test the patients sat comfortably on a couch, and in order to minimize the possible effects of somatic movement on motility, care was taken to ensure that they remained in the same posture throughout the study.

\section{Results}

INTRALUMINAL PRESSURES

The number of studies available for analysis is shown in Table I. Results of analysis of the pressure records are presented in Tables II and III, and the calculated differences between various observation periods are listed in Tables IV and V for $\mathrm{MI}$ and percentage duration of activity $N$ respectively.

\section{BASAL ACTIVITY}

There were no significant differences within each $\stackrel{\mathcal{D}}{\stackrel{9}{+}}$ of the three diagnostic groups between any of the $\square$ three 10-minute pre-meal periods at any of the sites studied, indicating that the observations $\cong$ were adequately controlled. Nor were there any $\frac{\mathbb{Q}}{\varnothing}$ significant differences in mean activity during the $O$ 30-minute period before the meal between the three diagnostic groups at the three sites studied.

\section{ACTIVITY DURING THE MEAL}

The time taken to eat the standard meal was similar in the three groups, averaging $13.0 \mathrm{~min}$ 
in the total gastrectomy, $12.4 \mathrm{~min}$ in the pernicious anaemia, and $10.0 \mathrm{~min}$ in the duodenal ulcer patients.

Stimulation of activity was prompt and within two to three minutes of the first mouthful of food; it continued throughout the meal in all the groups. The increase in colonic activity during the meal was significantly higher than the basal activity with respect to one or both variables of motility in all the groups, with the exception of the sigmoid in the pernicious anaemia patients (Tables IV and V). Comparisons between the three groups of patients showed no difference in activity at any site during the meal.
ACTIVITY AFTER THE MEAL

The increase in motor activity which began during the meal continued throughout the postprandial half-hour. One or both variables of motility were significantly higher than basal values at all three sites in each of the three groups of patients (Tables IV and V).

Comparisons of activity during the postprandial half-hour between the three diagnostic groups showed a similar response of the proximal colon and rectum, but some aspects of sigmoid activity in the total gastrectomy group differed from the sigmoid activity of patients with pernicious anaemia or duodenal ulcer. The motor response

\begin{tabular}{|c|c|c|c|c|}
\hline \multirow[b]{2}{*}{ Site } & \multirow[b]{2}{*}{ Group } & \multicolumn{3}{|c|}{ Periods Compared (Differences of Means $\pm S E$ of Differences) } \\
\hline & & $\begin{array}{l}\text { Meal v. Mean of } \\
\text { (Pre-meal } 1,2,3)\end{array}$ & $\begin{array}{l}\text { Meal v. Mean of } \\
\text { (Post-meal } 1,2,3)\end{array}$ & $\begin{array}{l}\text { Mean of }(\text { Post-meal } 1,2,3) \\
\text { v. Mean of }(\text { Pre-meal } 1,2,3)\end{array}$ \\
\hline \multirow[t]{3}{*}{$\begin{array}{l}\text { Proximal } \\
\text { colon }\end{array}$} & \multirow{3}{*}{$\begin{array}{l}\text { Total } \\
\text { gas:rectomy } \\
\text { Pernicious } \\
\text { anaemia } \\
\text { Duodenal } \\
\text { ulcer }\end{array}$} & $0.25 \pm 0.21$ & $0.04 \pm 0.21$ & $0.21 \pm 0.15$ \\
\hline & & $0.54^{2} \pm 0.17$ & $-0.02 \pm 0.17$ & $0.56^{3} \pm 0.12$ \\
\hline & & $0.85^{3} \pm 0.22$ & $0.35 \pm 0.22$ & $0.50^{2} \pm 0.16$ \\
\hline \multirow[t]{3}{*}{ Sigmoid } & \multirow{3}{*}{$\begin{array}{l}\text { Total } \\
\text { gastrectomy } \\
\text { Pernicious } \\
\text { anaemia } \\
\text { Duodenal } \\
\text { ulcer }\end{array}$} & $0.59^{3} \pm 0.16$ & $-0.23 \pm 0.16$ & $0 \cdot 82^{8} \pm 0 \cdot 12$ \\
\hline & & $0.24 \pm 0.16$ & $-0.06 \pm 0.16$ & $0.30^{1} \pm 0.11$ \\
\hline & & $0.57^{3} \pm 0.13$ & $0.21 \pm 0.13$ & $0.36^{3} \pm 0.09$ \\
\hline \multirow[t]{3}{*}{ Rectum } & \multirow{3}{*}{$\begin{array}{l}\text { Total } \\
\text { gastrectomy } \\
\text { Pernicious } \\
\text { anaemia } \\
\text { Duodenal } \\
\text { ulcer }\end{array}$} & $0.52^{1} \pm 0.23$ & $0 \cdot 17 \pm 0 \cdot 23$ & $0.35^{1} \pm 0.17$ \\
\hline & & $0.48^{2} \pm 0.16$ & $0.09 \pm 0.16$ & $0.39^{2} \pm 0.11$ \\
\hline & & $0.48^{2} \pm 0.17$ & $0.20 \pm 0.17$ & $0.28^{1} \pm 0 \cdot 12$ \\
\hline
\end{tabular}

Table IV Comparison of observation periods: $\log M I$

\begin{tabular}{|c|c|c|c|c|}
\hline \multirow[b]{2}{*}{ Site } & \multirow[b]{2}{*}{ Group } & \multicolumn{3}{|c|}{ Periods Compared (Differences of Means $\pm S E$ of Differences) } \\
\hline & & $\begin{array}{l}\text { Meal v. Mean of } \\
\text { (Pre-meal 1, 2,3) }\end{array}$ & $\begin{array}{l}\text { Mealv. Mean of } \\
(\text { Post-meal } 1,2,3)\end{array}$ & $\begin{array}{l}\text { Mean of (Post-meal 1, 2,3) } \\
\text { v. Mean of (Pre-meal 1, 2, 3) }\end{array}$ \\
\hline \multirow[t]{3}{*}{$\begin{array}{l}\text { Proximal } \\
\text { colon }\end{array}$} & \multirow{3}{*}{$\begin{array}{l}\text { Total } \\
\text { gastrectomy } \\
\text { Pernicious } \\
\text { anaemia } \\
\text { Duodenal } \\
\text { ulcer }\end{array}$} & $11 \cdot 3^{1} \pm 5 \cdot 2$ & $-5 \cdot 2 \pm 5 \cdot 2$ & $16 \cdot 5^{3} \pm 3 \cdot 7$ \\
\hline & & $15 \cdot 2^{1} \pm \cdot 51$ & $1 \cdot 4 \pm 5 \cdot 1$ & $13 \cdot 8^{3} \pm 3 \cdot 6$ \\
\hline & & $28 \cdot 8^{3} \pm 5 \cdot 8$ & $16 \cdot 6^{2} \pm 5 \cdot 8$ & $12 \cdot 2^{2} \pm 4 \cdot 1$ \\
\hline \multirow[t]{3}{*}{ Sigmoid } & \multirow{3}{*}{$\begin{array}{l}\text { Total } \\
\text { gastrectomy } \\
\text { Pernicious } \\
\text { anaemia } \\
\text { Duodenal } \\
\text { ulcer }\end{array}$} & $24 \cdot 0^{3} \pm 5 \cdot 5$ & $-17 \cdot 7^{2} \pm 5 \cdot 5$ & $41 \cdot 7^{3} \pm 3.9$ \\
\hline & & $9 \cdot 8 \pm 5 \cdot 1$ & $-4 \cdot 1 \pm 5 \cdot 1$ & $13 \cdot 9^{3} \pm 3 \cdot 6$ \\
\hline & & $29 \cdot 4^{3} \pm 4 \cdot 5$ & $9 \cdot 6^{1} \pm 4 \cdot 5$ & $19 \cdot 8^{3} \pm 3 \cdot 2$ \\
\hline \multirow[t]{3}{*}{ Rectum } & \multirow{3}{*}{$\begin{array}{l}\text { Total } \\
\text { gastrectomy } \\
\text { Pernicious } \\
\text { anaemia } \\
\text { Duodenal } \\
\text { ulcer }\end{array}$} & $14 \cdot 4^{2} \pm 4 \cdot 4$ & $0 \cdot 2 \pm 4 \cdot 4$ & $16 \cdot 2^{2} \pm 3 \cdot 1$ \\
\hline & & $8 \cdot 7^{1} \pm 3 \cdot 6$ & $3 \cdot 5 \pm 3 \cdot 6$ & $5 \cdot 2^{1} \pm 2 \cdot 5$ \\
\hline & & $18 \cdot 2^{3} \pm 5 \cdot 0$ & $7.7 \pm 5.0$ & $10 \cdot 5^{2} \pm 3.6$ \\
\hline
\end{tabular}

Table V Comparison of observation periods: percentage activity 

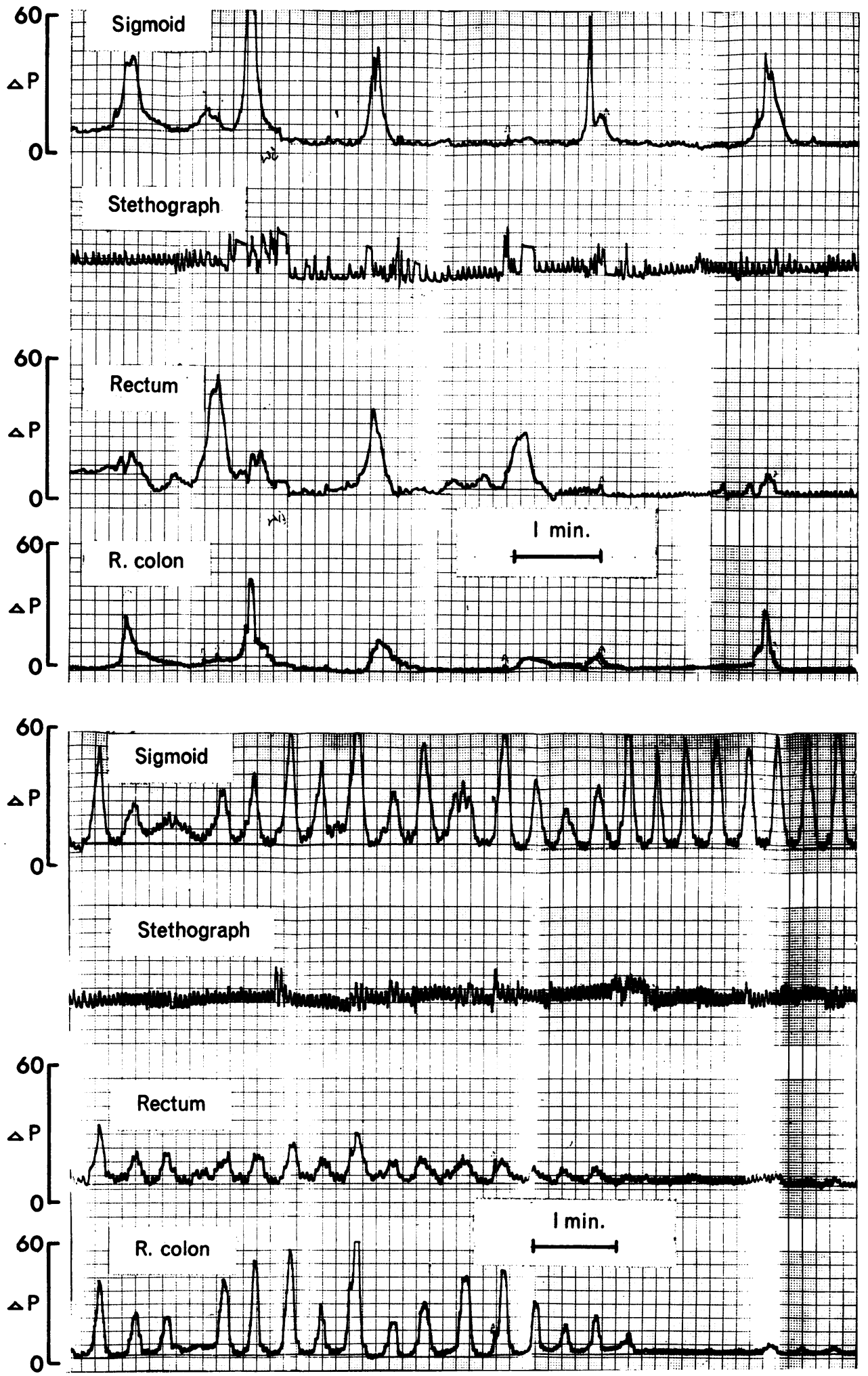

Fig. 2 Total gastrectomy patient. Simultaneous pressure records from the sigmoid, rectum, and right colon (top) before, and after, a meal. Pressure scale in $\mathrm{cm} \mathrm{H}_{2} \mathrm{O} . \triangle P$ is the change in intraluminal pressure. Marked increase of activity in sigmoid after a meal. 


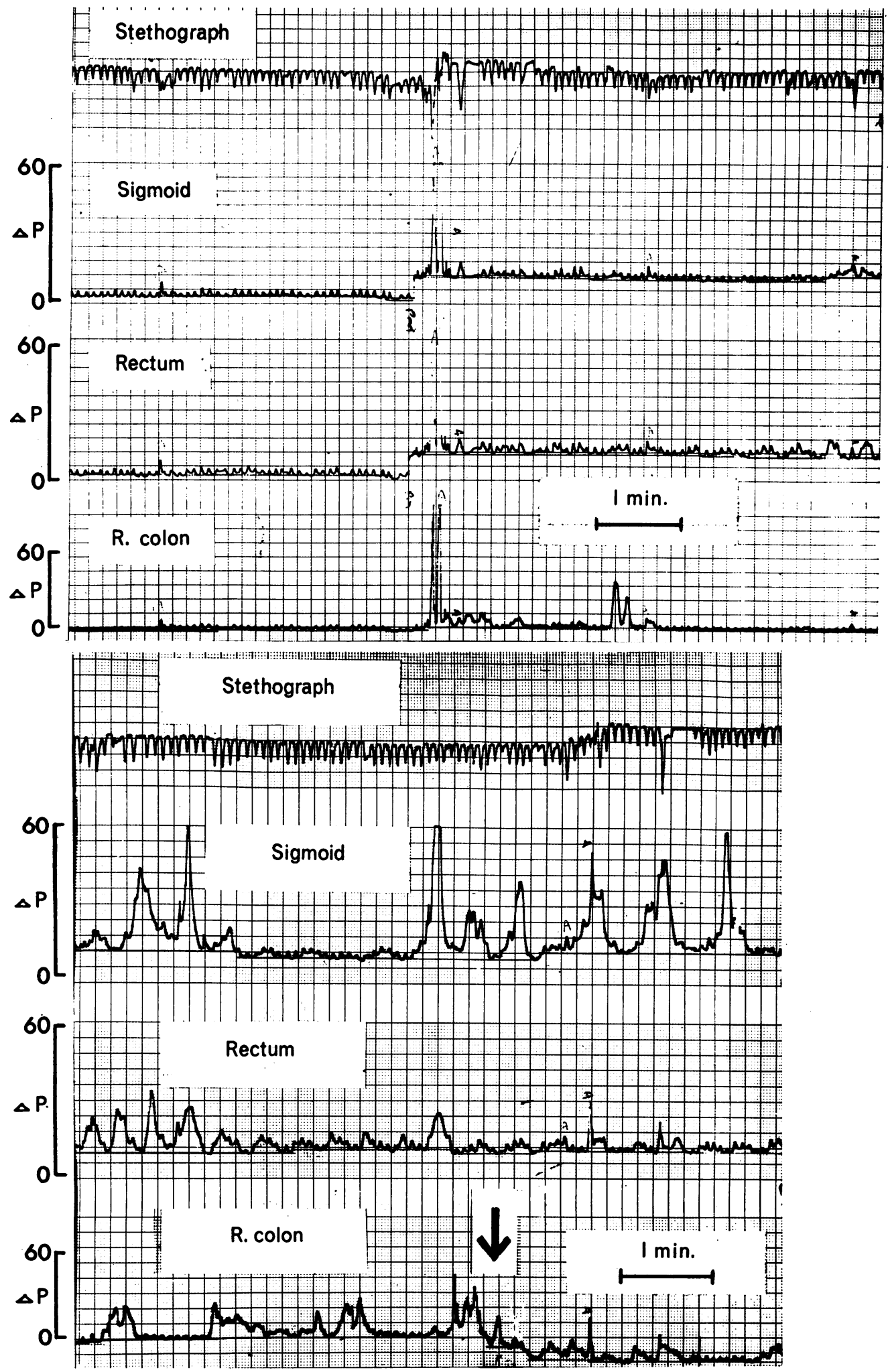

Fig. 3 Duodenal ulcer patient. Simultaneous pressure records from the sigmoid, rectum and right colon (top) before, and after, a meal. Pressure scale in $\mathrm{cm} \mathrm{H}_{2} \mathrm{O}$. Note change of baseline (arrowed) in telemetred record from right colon. 


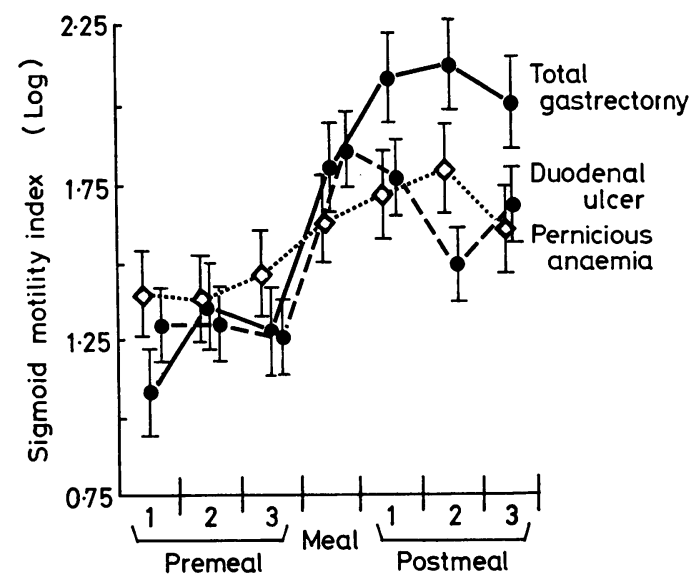

Fig. 4 Sigmoid colon. Log motility index (ordinate) during the observation periods (abscissa). Bars $= \pm \mathrm{SE}$ of means.

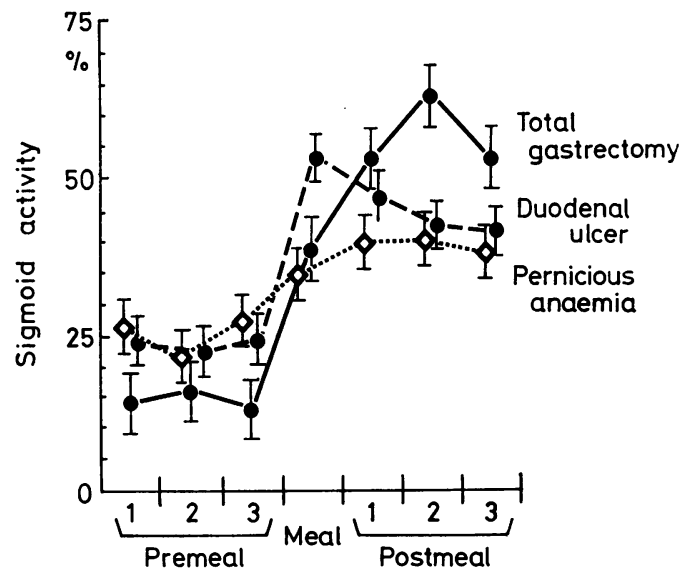

Fig. 5 Sigmoid colon. Percentage duration of activity (ordinate) during the observation periods (abscissa). Bars $= \pm \mathrm{SE}$ of means.

\begin{tabular}{|c|c|c|c|}
\hline \multirow[t]{2}{*}{ Variable of Motility } & \multicolumn{3}{|l|}{ Comparisons } \\
\hline & $\begin{array}{l}\text { Total Gastrectomy } \mathbf{v} \\
\text { Pernicious Anaemia }\end{array}$ & $\begin{array}{l}\text { Total Gastrectomy } \\
\text { Duodenal Ulcer }\end{array}$ & $\begin{array}{l}\text { v. Pernicious Anaemiav. } \\
\text { Duodenal Ulcer }\end{array}$ \\
\hline $\begin{array}{l}\text { Log MI } \\
\text { Percentage activity }\end{array}$ & $\begin{array}{l}0 \cdot 51^{1} \pm 0 \cdot 21 \\
28 \cdot 6^{3} \pm 8 \cdot 4\end{array}$ & $\begin{array}{l}0 \cdot 44^{2} \pm 0 \cdot 17 \\
20 \cdot 2^{3} \pm 6 \cdot 3\end{array}$ & $\begin{array}{c}0.07 \pm 0.18 \\
8.4 \pm 6.5\end{array}$ \\
\hline
\end{tabular}

Table VI Sigmoid colon: comparisons between responses to the meal (differences between mean activity in pre- and post-meal half-hours $\pm \mathrm{SE}$ of differences)

${ }^{1} \mathrm{P}<0.05 \quad{ }^{2} \mathrm{P}<0.02 \quad{ }^{3} \mathrm{P}<0.01$ of the sigmoid in total gastrectomy patients is clear on inspection of the pressure records (Figs $\ddot{\Rightarrow}$ $2 \mathrm{a}$ and $\mathrm{b}$ ), but in the other diagnostic groups the $\stackrel{\oplus}{+}$ response although clearly present, was less strik- $\frac{}{C}$ ing (Figs 3a and $b$ ). Data for the sigmoid colon for MI and percentage duration of activity which are summarized in Figs 4 and 5 and in $\varrho$ Tables II to $\mathrm{V}$, suggest that the sigmoid response क may have been greater and longer sustained in $\overrightarrow{0}$ the total gastrectomy group than in the other patients. At the time of peak activity after the $\vec{\omega}$ meal, ie, during the second post-meal period, $\stackrel{\circ}{\circ}$ (Figs 4 and 5), the percentage duration of activity was greater in the total gastrectomy than $\overrightarrow{-}$ in the pernicious anaemia patients $(P<0.05)$, i though just failing to reach the conventional $\vec{\circ}$ levels of significance on comparison with the duodenal ulcer group.

Colonic motor response to meals may be defined as the difference between levels of motor activity $\mathbb{D}$ in half-hours before and after the meal. Comparisons between the three diagnostic categories carried out in this way show a significantly greater sigmoid response in the total gastrectomy patients than in others, whilst there are no significant differences between the responses of patients with duodenal ulcer or pernicious anaemia (Table VI). The validity of this comparison depends on there being no significant $\stackrel{0}{\circ}$ difference in the levels of basal motility between $\stackrel{\mathbb{Q}}{\circ}$ the three groups, and this was so in the present $\overrightarrow{\overrightarrow{0}}$ study. However, basal percentage duration of $\exists$ activity tended to be low in the total gastrectomy group (Fig 5), although no such difference was apparent with respect to MI (Figure 4).

There were no differences between the responses to the meal of the proximal colon or the rectum between any of the three groups of patients.

EFFECT OF ACID SECRETION ON POSTPRANDIAL MOTILITY

Acid secretion of the duodenal ulcer patients was in the usual range for this condition (mean $\sigma$ basal hour 6.5 m-equiv; $S E \pm 1.8$; mean peak $N$ hour $45 \cdot 1$ m-equiv; $S E \pm 4 \cdot 8$ ). There was no correlation between maximal acid output and the increase in variables of sigmoid motility, regard- less of whether correlations were made with the $\overbrace{\mathbb{D}}$ period of highest motor activity, or with the $\stackrel{?}{+}$ overall differences between pre- and post- 0 prandial activity in individual patients.

\section{PROPULSIVE ACTIVITY AND TRANSIT TIMES}

Propulsion of the radiotelemetering capsule was observed on only one occasion in this study, in aO duodenal ulcer patient with a normal bowel habit, whose pressure record is shown in Figure 3. $\frac{\bar{a}}{7}$ At the start of the study the radiocapsule was in the right colon (Fig 6a), whilst one and threequarter hours later it had moved to the region of the splenic flexure (Figure 6b). Although the 


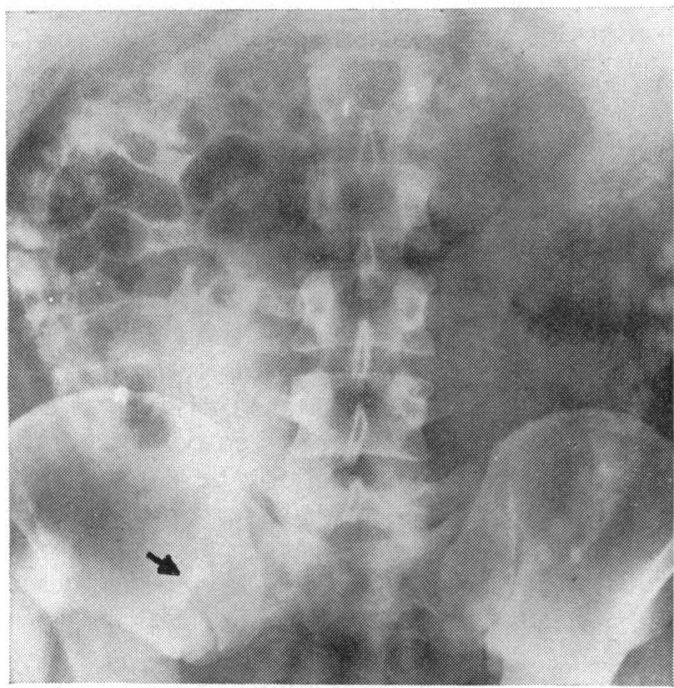

Fig. 6 Plain radiographs of abdomen at (left) start and (right) finish of study. Radiotelemetering capsule (arrowed) in right colon (on the left) has been propelled to splenic flexure (on the right). (Same patient as in Figure 3.) radiopaque pellets were partially obscured by residual contrast medium from a recent barium meal, inspection of the films suggested that they and the barium had shared in the movement. Sudden shift of an otherwise stable baseline (arrowed in Fig 3b) suggests the onset of propulsive activity, but as signal strength of the radiotelemetering capsule (Misiewicz, 1968c) was not being measured, it is not possible to decide with certainty when the movement occurred.

The results of measurements of transit with pellets and radiotelemetering capsules are summarized in Table VII and show that transit times of both markers were similar. Transit time was shortest in the patients with total gastrectomy and slowest in those with pernicious anaemia, although these differences were not significant.

\section{Discussion}

The gastro-colic reflex as described by Hurst (1919) clearly means extensive propulsive activity (mass movement) of the colon, whilst Barclay (1935) was able to differentiate between propulsive and non-propulsive colonic motor activity. Clinically, gastro-colic reflex implies defaecation after a meal, usually breakfast. The 'working' of a colostomy after meals is another example of the reflex. Increased colonic pressure activity

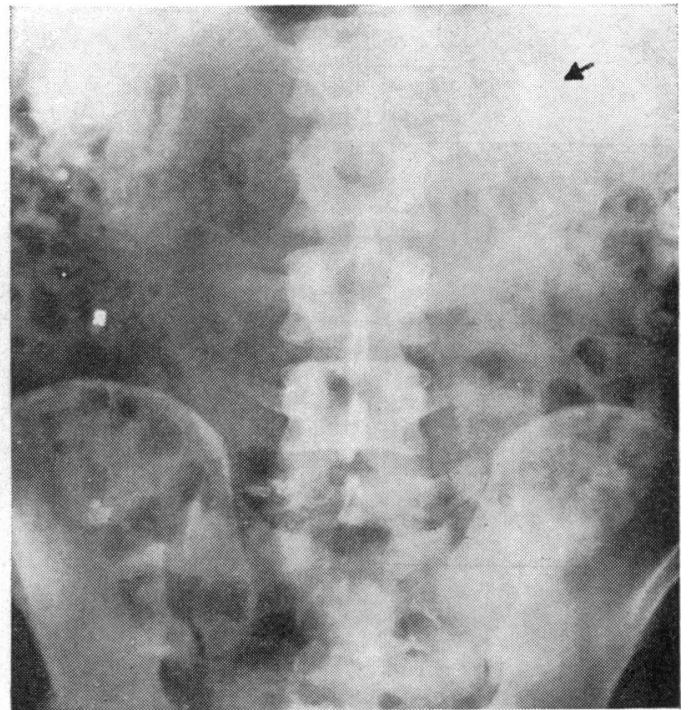

during and after meals has been shown to take place without the stomach. Moreover, if patients are immobile, as in our studies, increased pressure activity was not associated (except in one patient) with propulsion. For these reasons the term 'gastro-colic' reflex seemed inappropriate to describe the changes observed in this study, and the term colonic pressure response to food is used instead. The occurrence of colonic propulsion or of defaecation in the postprandial period may depend on other factors, such as faecal loading of reflexogenic areas, or somatic activity (Holdstock et al, 1970).

Results of this study show that the colonic pressure response to food is similar in patients with total gastrectomy, pernicious anaemia, or duodenal ulcer in the proximal colon and rectum, whilst the response of the sigmoid is, in some respects, greater in the total gastrectomy group than in the other two diagnostic categories. These findings can be interpreted in the light of known clinicopathological changes after total gastrectomy, in pernicious anaemia, or in duodenal ulcer. In the absence of a gastric reservoir food enters the small intestine directly, without dilution by, or mixing with, gastric secretions. Mechanical distension of the upper small intestine is therefore likely. Secondly, patients with total gastrectomy have had a truncal vagotomy and often have steatorrhoea, both of which may affect the intestinal transit rate. Thirdly, they are unable 


\begin{tabular}{|c|c|c|c|c|c|c|}
\hline \multirow[t]{2}{*}{ Group } & \multicolumn{3}{|c|}{$80 \%$ of Pellets } & \multicolumn{3}{|c|}{ Radiotelemetering Capsule } \\
\hline & $\begin{array}{l}\text { No. of } \\
\text { Patients }\end{array}$ & $\begin{array}{l}\text { Transit Tin } \\
\text { Mean }( \pm S\end{array}$ & $\begin{array}{l}\text { hr) } \\
\text { Range }\end{array}$ & $\begin{array}{l}\text { No. of } \\
\text { Patients }\end{array}$ & $\begin{array}{l}\text { Transit Ti } \\
\text { Mean }( \pm\end{array}$ & $\begin{array}{l}h r) \\
\text { l) Range }\end{array}$ \\
\hline \multirow{3}{*}{$\begin{array}{l}\text { Total } \\
\text { gastrectomy } \\
\text { Pernicious } \\
\text { anaemia } \\
\text { Duodenal } \\
\text { ulcer }\end{array}$} & 5 & $41( \pm 8)$ & $18-60$ & 4 & $34( \pm 9)$ & $11-57$ \\
\hline & 5 & $75( \pm 26)$ & $12-156$ & 5 & $70( \pm 27)$ & $12-156$ \\
\hline & 5 & $57( \pm 11)$ & $15-83$ & 6 & $45( \pm 8)$ & $10-59$ \\
\hline
\end{tabular}

Table VII Transit times

to secrete antral gastrin in response to food.

Patients with pernicious anaemia secrete no gastric acid or intrinsic factor but there is no reason to implicate the latter in the control of motility. On the other hand gastrin is localized in specific cells of the antral mucosa (McGuigan, 1968), which does not share in the mucosal atrophy of the gastric body (Morson, 1966). Secretion of antral gastrin in pernicious anaemia may therefore be normal or high, especially as there is no acidification of the antrum to inhibit the release of the antral hormone.

Our patients with duodenal ulcer had a norma! or raised acid output, and were therefore likely to acidify the duodenum at least intermittently (Rhodes and Prestwick, 1966; Watson, Watt, Paton, Glen, and Lewis, 1966). Gastric emptying is faster in patients with duodenal ulcer than in normals (Griffiths, Owen, Campbell, and Shields, 1968), but it is not known how it compares with the rate of gastric emptying in patients with pernicious anaemia. At the time of writing there was no information on the postprandial levels of circulating gastrin in patients with duodenal ulcer but it is likely to be normal or high.

Since the response of the gastrectomized patients was as marked as, if not greater than, that of the other groups, it is unlikely that gastrin is the major factor mediating the colonic pressure response to food. This conclusion agrees well with previous studies in vitro and in vivo of the effect of gastrin and pentagastrin on the human gastrointestinal tract (Bennett, Misiewicz, and Waller, 1967; Misiewicz, Holdstock, and Waller, 1967; Misiewicz et al, 1969b). Although it could be argued that gastrin inhibits colonic muscle, such an effect has never been demonstrated. Truncal vagotomy may occasionally be followed by diarrhoea, but our patients with total gastrectomy had a normal bowel habit and the sigmoid is not innervated by the vagus.

Although acidification of the duodenum is known to trigger the release of intestinal hormones and to affect various aspects of gastro-intestinal function, eg, gastric secretion or motor activity $\vec{\Rightarrow}$ (Johnston and Duthie, 1966; Misiewicz et al, 1967, $\stackrel{\text { की }}{?}$ $1969 \mathrm{~b})$, it is unlikely that acidification of the duodenum stimulated colonic activity, since the colonic $\frac{\bar{\sigma}}{\bar{\omega}}$. motor response to food was of the same order in $\frac{\vec{\sigma}}{\vec{\sigma}}$ patients with pernicious anaemia and in those $\varrho$ with duodenal ulcer. Moreover, in the latter $\%$ group there was no correlation between output $\overrightarrow{0}$ of acid and the colonic response to food. This $\overrightarrow{\vec{H}}$ conclusion is further supported by previous $\vec{\omega}$ observations (Misiewicz et al, 1967 and 1969b).

The rapid entry of food into the small intestine? may therefore be of major importance in initiating $\overrightarrow{\vec{A}}$ postprandial colonic pressure activity whilst the less marked sigmoid response of patients with $\vec{\circ}$ duodenal ulcer or pernicious anaemia may be due to the slower arrival of the ingested meal in the jejunum.

A stimulus to the upper small intestine could $\mathbb{D}$ affect the colon in several ways, eg, by a spinal reflex, through the intramural nervous plexus, by the release of polypeptide hormones, such as $\overrightarrow{0}$ secretin or cholecystokinin-pancreozymin, or other biogenic substances, eg 5-hydroxytryptamine $(5 \mathrm{HT})$, bradykinin, or prostaglandins. The chemical or mechanical effects of ileal contents entering the caecum may likewise be important. Several mechanisms may be active simultaneously. Thus the rapid increase of colonic motor activity within a few minutes of the first mouthful of food suggests a nervous pathway, whereas the maintenance of the response after the meal may be humoral. It may be relevant that activity during the meal was similar in the three study groups, whilst only in the total gastrectomy group was there a further increase in activity in the postprandial period.

Persistence of colonic response to food in patients with lesions of the lower spinal cord (Connell, Frankel, and Guttman, 1963) is against the importance of a spinal reflex pathway. The increased activity of the right colon after food in our studies suggests that mechanical or chemical stimuli of ileal contents may be responsible. On the other hand, distension or changes of osmolarity and $p \mathrm{H}$ in the colonic lumen have been shown to be relatively ineffective stimulants of distal bowel motility (Hardcastle and Mann, in press), and pressure activity after meals occurs in the defunctioned limb of double-barrelled colostomies, indicating that the response is not wholly dependent on stimuli originating in the bowel lumen (Hardcastle, Misiewicz, and Kiley, in preparation).

In the dog, the ideal response to feeding is conducted by the intramural plexus (Douglas and Mann, 1940), but these authors were unable to show a similar effect in the colon. However, clinical and experimental evidence in man indicates that intramural nerves are essential to the normal functioning of the colon, and they can mediate peristaltic activity in response to local 
chemical stimulation of the mucosa (Bodian, Stephens, and Ward, 1949; Köberle, 1963; Hardcastle and Mann, 1968; Dyer, Dawson, Smith, and Todd, 1969).

That a humoral mechanism is implicated in the colonic response is suggested by the observations of Frigo, Crema, and Benzi (quoted by Torsoli, Ramorino, and Crucioli, 1968), who reported increased colonic activity after feeding in crosscirculation experiments on cats. Of the possible hormonal mediators other than gastrin, secretin and cholecystokinin-pancreozymin haveobviously to be considered, and have been isolated in pure form (Jorpes and Mutt, 1961; Jorpes, Mutt, and Tocsko, 1964). Most studies in man have so far been made with relatively impure preparations, which have been noticed in passing to stimulate the small intestine in man (Burton, Evans, Harper, Howat, Oleesky, Scott, and Varley, 1960), but their effect on the colon is not known. In vitro, cholecystokinin-pancreozymin seems to have little effect on isolated strips of human colonic muscle (Misiewicz and Waller, unpublished observations). The possible role of secretin as the agent causing diarrhoea in pathological states has been studied (Zollinger, Tompkins, Amerson, Endhal, Kraft, and Moore, 1968), but little is known of its effect on colonic motility, although changes in the colonic mucosa have been reported (Johansen, Hadorn, and Anderson, 1968).

The presence of a Roux-en-Y or jejunal reservoir type of reconstruction in the total gastrectomy patients suggests that entry of food into the upper jejunum, rather than the duodenum, can inititate the colonic response. As none of the patients had symptoms of dumping, the level of plasma kinin was unlikely to be high (Zeitlin and Smith, 1966), and bradykinin is known to relax isolated human colonic muscle strips, except in high concentrations (Fishlock, 1966). For similar reasons, it is not likely that $5 \mathrm{HT}$ was the mediator of the colonic response (Misiewicz, Waller, and Eisner, 1966). Of other possible mediators, various prostaglandins can cause diarrhoea when secreted by certain tumours (Williams, Karim, and Sandler, 1968; Sandler, Karim, and Williams, 1968) but increased rate of intestinal transit after oral prostaglandin $\mathrm{E}_{1}$ was not associated with a marked increase in colonic pressure activity (Misiewicz, Waller, Kiley, and Horton, 1969a).

None of these agents therefore qualifies as the obvious transmitter for the colonic pressure response to eating. However, the present observations indicate that this response does not require the presence of the stomach, gastrin, acid, or of the vagus nerve but depends in some way on entry of food into the upper small intestine. This raises the question whether the rate of gastric emptying is relevant to the regulation of colonic function in health and disease. That this may be so is indicated by the recent findings of Connell and McKelvey (1970) that postvagotomy diarrhoea is associated with rapid gastric emptying.
We thank Dr F. Avery Jones, Dr T. D. Kellock, and Dr J. P. Knowles for permission to study their patients, and Mr M. J. R. Healy, M. R. C. Clinical Research Centre, for advice on the statistical analysis of the data. We are grateful to the dietitians for supplying the test meals, to Mr A. Booker, FPS, Department of Photography, for the illustrations and to Mrs Moira Black, Mrs E. E. Cox and Miss Nancy Kiley, BSc, Department of Gastroenterology, for technical assistance.

\section{References}

Arfwidsson, S. (1964). Pathogenesis of multiple diverticula of the sigmoid colon in diverticular disease. Acta chir. scand., Suppl., 342.

Atkinson, M., Edwards, D. A. W., Honour, A. J., and Rowlands, E. N. (1957). Comparison of the cardiac and pyloric sphincters. A manometric study. Lancet, 2, 918-922.

Barclay, A. E. (1935). Direct $x$-ray cinematography with a preliminary note on the nature of the non-propulsive movements of the large intestine. Brit. J. Radiol., 8 , 652-658.

Baron, J. H. (1963). An assessment of the augmented histamine test in the diagnosis of peptic ulcer. Gut, 4, 243-253.

Bennett, A., Misiewicz, J. J., and Waller, S. L. (1967). Analysis of the motor effects of gastrin and pentagastrin on the human alimentary tract in vitro. Gut, 8, 470-474.

Bodian, M., Stephens, F. D., and Ward, B. C. H. (1949). Hirschsprung's disease and idiopathic megacolon. Lan et, 1, 6-11.

Burton, P., Evans, D. G., Harper, A. A., Howat, H. T., Oleesky, S., Scott, J. E., and Varley, H. (1960). A test of pancreatic function in man based on the analysis of duodenal contents after administration of secretin and pancreozymin Gut, 1, 111-124.

Chaudhary, N. A., and Truelove, S. C. (1962). The irritable colon syndrome. Quart. J. Med., N.S., 31, 307-322.

Connell, A. M., Frankel, H., and Guttman, L. (1963). The motility of the pelvic colon following complete lesions of the spinal cord. Paraplegia, 1, 98-115.

Connell, A. M., Jones, F. A., and Rowlands, E. N. (1965). The motility of the pelvic colon. IV Abdominal pain associated with colonic hypermotility after food. Gut, 6, 105-112.

Connell, A. M., and McKelvey, S. T. D. (1970). Proc. roy. Soc. Med., in the press.

Douglas, D. M., and Mann, F. C. (1940). The gastroileac reflex: further experimental observations. Amer. J. dig. Dis., 7, 53-57.

Dyer, N. H., Dawson, A. M., Smith, B. F., and Todd, I. P. (1969). Obstruction of bowel due to lesion in the myenteric plexus. Brit. med. J., 686-689.

Fishlock, D. J. (1966). Effect of bradykinin on the human isolated small and large intestine. Nature (Lond.), 212, 1533-1535.

Griffith, G. H., Owen, G. M., Campbell, H., and Shields, R. (1968). Gastric emptying in health and in gastrointestinal disease. Gastroenterology, 54, 1-7.

Halls, J. (1965). Bowel content shift during normal defaecation. Proc. roy. Soc. Med., 58, 859-860.

Hardcastle, J. D., and Mann, C. V. (1968). Study of large bowel peristalsis. Gut, 9, 512-520.

Hardcastle, J. D., and Mann, C. V. (1970). Physical factors in the stimulation of colonic peristalsis. Gut, 11 41-46.

Hinton, J. M. (1967). Laxatives and anti-diarrhoeal agents; transit studies. Proc. roy. Soc. Med., 60, 215-216.

Hinton, J. M., Lennard-Jones, J. E., and Young, A. C. (1969). A new method for studying gut transit times using radiopaque markers. Gut, 10, 842-847.

Holdstock, D. J., Misiewicz, J. J., Smith, T., and Rowlands, E. N. (1970). Propulsion (mass movements) in the human colon and its relationship to meals and somatic activity. Gut, 11, 91-99.

Holdstock, D. J., Misiewicz, J. J., and Waller, S. L. (1969) Observations on the mechanism of abdominal pain. Gut, 10, 19-31.

Hurst, A. F. (1919). Constipation and Allied Intestinal Disorders. 2nd ed. Frowde, London.

Johansen, P. G., Hadorn, B., and Anderson, D. M. (1968) Effect of secretin on human rectal mucosa in vivo. Nature (Lond.), 217, 468.

Johnston, D., and Duthie, H. L. (1966). Inhibition of histaminestimulated gastric secretion by acid in the duodenum in man. Gut, 7, 58-68.

Jorpes, J. R., and Mutt, V. (1961). On the biological activity and amino acid composition of secretin. Acta chem. scand., 15, 1790-1791. 
Jorpes, J. E., Mutt, V., and Tocsko, K. (1964). Further purification of cholecystokinin and pancreozymin. Acta chem. scand., 18, 2408-2410.

Köberle, F. (1963). Enteromegaly and cardiomegaly in Chagas disease. Gut, 4, 399-405.

McGuigan, J. E. (1968). Gastric mucosal intracellular localisation of gastrin by immunofluorescence. Gastroenterology, 55, 315-327.

Misiewicz, J. J., Waller, S. L., and Eisner, M. (1966). Motor responses of the human gastrointestinal tract to 5hydroxytryptamine in vivo and in vitro. Gut, 7, 208-216.

Misiewicz, J. J., Holdstock, D. J., and Waller, S. L. (1967). Motor responses of the human alimentary tract to nearmaximal infusions of pentagastrin. Gut, 8, 463-469.

Misiewicz, J. J., Waller, S. L., Fox, R. H., Goldsmith, R., and Hunt, T. J. (1968a). The effect of elevated body temperature, and of stress on the motility of stomach and colon in man. Clin. Sci., 34, 149-159.

Misiewicz, J. J., Waller, S. L., Healy, M. J. R., and Piper, E. A. (1968b). Computer anaysis of intraluminal pressure records. Gut, 9, 232-236.

Misiewicz, J. J. (1968c). Measurement of intraluminal pressures. Radiotelemetering, design of manometric studies, and computer analysis of records. Amer. J. dig. Dis., N.S., 13, 389-396.

Misiewicz, J. J., Waller, S. L., Kiley, N., and Horton, E. W. (1969a). The effect of oral prostaglandin $E_{1}$ on intestinal transit in man. Lancet, 1, 648-651.

Misiewicz, J. J., Waller, S. L., and Holdstock., D. J. (1969b). Gastrointestinal motility and gastric secretion during intravenous infusions of gastrin II. Gut, 10, 728-729.

Morson, B. C. (1963). The muscle abnormality in diverticular disease of the colon. Brit. $J$ Radiol., 36, 385-392.

Morson, B. C. (1966). The stomach, In: Systemic Pathology, vol. 1, edited by G. Payling Wright and W. St. C. Symmers. Longmans, London.

Painter, N. S. S., Truelove, S. C., Ardran, G. M. and Tuckey, M. (1965). Effect of morphine, prostigmine, pethidine, and probanthine on the human colon in diverticulosis studied by intraluminal pressure recording and cineradiography. Gut, 6, 57-63.

Rhodes, J., and Prestwick, C. J. (1966). Acidity at different sites in the proximal duodenum of normal subjects and patients with duodenal ulcer. Gut, 7, 509-514.

Rowlands, E. N., and Wolff, H. S. (1960). The radiopill. Telemetering from the digestive tract. Brit. Commun. Electron., 7, 598-601.

Sandler, M., Karim, S. M. M., and Williams, E. D. (1968). Prostaglandins and amine-peptide-secreting tumours. Lancet, 2, 1053-1055.
Torsoli, A., Ramorino, M. L., and Crucioli, V. (1968). The relationship between anatomy and motor activity of the colon. Amer. J. dig. Dis., N.S., 13, 462-467.

Watson, W. C., Watt, J. K., Paton, E. Glen, A., and Lewis, G. J. T. (1966). Radiotelemetering studies of jejunal pH before and after vagotomy and gastroenterostomy. Gut, 7 , 700-705.

Williams, E. D., Karim, S. M. M., and Sandler, M. (1968). Prostaglandin secretion by medullary carcinoma of the thyroid. Lancet, 1, 22-23.

Wormsley, K. G., and Crossman, M. I. (1965). Maximal histalog test in control subjects and patients with peptic ulcer. Gut, 6, 427-435.

Zeitlin, I. J., and Smith, A. N. (1966). 5-Hydroxyindoles and kinins in the carcinoid and dumping syndromes. Lancet, 2, 986-991.

Zollinger, R. M., Tompkins, R. K., Amerson, J. R., Endahl, G. L., Kraft, A. R., and Moore, F. T. (1968). Identification of the diarrheagenic hormone associated with non-beta islet cell tumours of the pancreas. Ann. Surg., 168, 502-521. 